\title{
8. PRE-SITE SURVEY OF THE JAPAN TRENCH TRANSECT, DEEP SEA DRILLING PROJECT
}

\author{
Eiichi Honza, Geological Survey of Japan, Tsukuba, Japan
}

\section{INTRODUCTION}

A cruise for marine geological and geophysical investigations in the Japan and Kuril Trench areas was carried out by the research vessel Hakurei-Maru, as part of a research project of the Geological Survey of Japan. The cruise covered the whole area of the frontal slope of the Tohoku Arc, Japan Trench, southern frontal slope of the Kuril Arc, and the southern Kuril Trench, with surveyed lines 15 nautical miles apart (Figure 1). A detailed survey was also carried out with survey lines 5 nautical miles apart around the proposed drill sites of the Japan Trench Transect (Figure 2). The work was summarized as a cruise report and a geological map of the Japan and southern Kuril Trenches and adjacent areas (Honza, 1977; Honza et al., 1978).

In this chapter I discuss the correlation of the sedimentary layers and structures which occur on the frontal slope of the Tohoku Arc on the basis of the Deep Sea Drilling Project results in the outer trench belt of the arc.

\section{Bathymetry}

The major trends of the topographic features are approximately parallel to the axis of the Japan Trench or to the coast line of the Tohoku area (Figure 3A and B). Although there are some relatively flat terraces at depths of 1000 to 2000 meters and 4000 to 5000 meters, they are not developed along the full length of the area. Trench slope breaks are in the depth range of 1500 to 3000 meters and are topographically represented by doming in structurally uplifted zones (Honza et al., 1977). Benches and small ridges on the inner trench slope are restricted in their development to lengths of approximately 60 nautical miles or less, and they tend to shallow toward the south, possibly because of a block structure on the inner trench slope. The trench floor has a V-shaped profile, suggesting that active underthrusting of the Pacific Plate beneath the arc prevents terrigenous sediment in the trench bottom from damming up.

Except in a few cases, horst and graben structures that develop on the outer trench slope generally do not continue to adjacent survey lines, which are separated by 15 nautical miles.

\section{Gravity Measurements}

A low free-air gravity anomaly is observed along the Japan Trench, where the gravity minimum is located on the landward side an average of $12 \mathrm{~km}$ from the trench axis (Nishimura and Murakami, 1977). Another minimum is observed in the mid-terrace area of the continental margin. Weak highs occur along the trench slope break and strong highs in places on the continental shelf. Basin-like minimums are suggested along the southern Hokkaido coast (Figures 4 and 5).

Although some of these anomalies are explained by topographic changes, minimums along the inner trench slope may suggest lighter material than that at the outer trench slope. Broad minimums are believed to be caused by the thick, basin-like deposits of younger sediments seen in the reflection profiles. Highs on the continental shelf are caused by topographic highs and by exposures of denser material.

\section{Geomagnetic Anomalies}

Geomagnetic anomalies in the offshore area of the Tohoku Arc are distinguished in the following threeareas (Murakami et al., 1977): (1) Typical oceanic magnetic anomalies that are lineated and have large amplitudes and relatively long wavelengths are observed not only over the Pacific floor but also over the inner trench slope area; (2) a magnetic quiet zone, which has negative values with few variations in amplitude, occurs on the continental slope or deep sea terrace; (3) continental positive anomalies lie along the south coast of Hokkaido and the Tohoku area east coast (Figure 6).

Magnetic lineations on the northwestern Pacific floor are well delineated by Uyeda and Vacquier (1968) and Larson and Chase (1972). Magnetic profiles along the Kuril Trench suggest identification with anomalies $M-5$ (118 m.y.B.P.) to $M-9$ (121 m.y.B.P.) of the northern Japanese set (Hilde et al., 1976; Murakami et al., 1977). Magnetic anomalies along the coast of the Tohoku area have also been delineated (Ogawa and Suyama, 1976; Segawa and Oshima, 1975). It is suggested that the anomalies are derived from mafic to ultramafic intrusives of the Mesozoic, which crop out in places along the coast of the Kitakami Mountains. Several minor anomalies of uncertain origin occur in the midslope area of the magnetic quiet zone. However, silicic plutonism is suggested by the drilling at Site 439 . If the plutonism occurred during the earliest Miocene, as suggested by Yanagisawa and Ozima in this volume, these anomalies may be correlated with silicic plutonism, which suggests earliest Miocene frontal arc volcanism beyond the main volcanic front.

\section{Continuous Seismic Reflection Profiling}

Continuous seismic reflection methods reveal one to a few kilometers of thickness of Neogene and Quaternary strata on the continental slope or deep sea terrace (Honza et al., 1977; Tamaki et al., 1977). Neogene layers are developed over the whole of the continental slope along the Japan Trench (Figure 7). The layers that can be seen in the reflection profiles are categorized into three types: a strongly alternated layer in the uppermost 


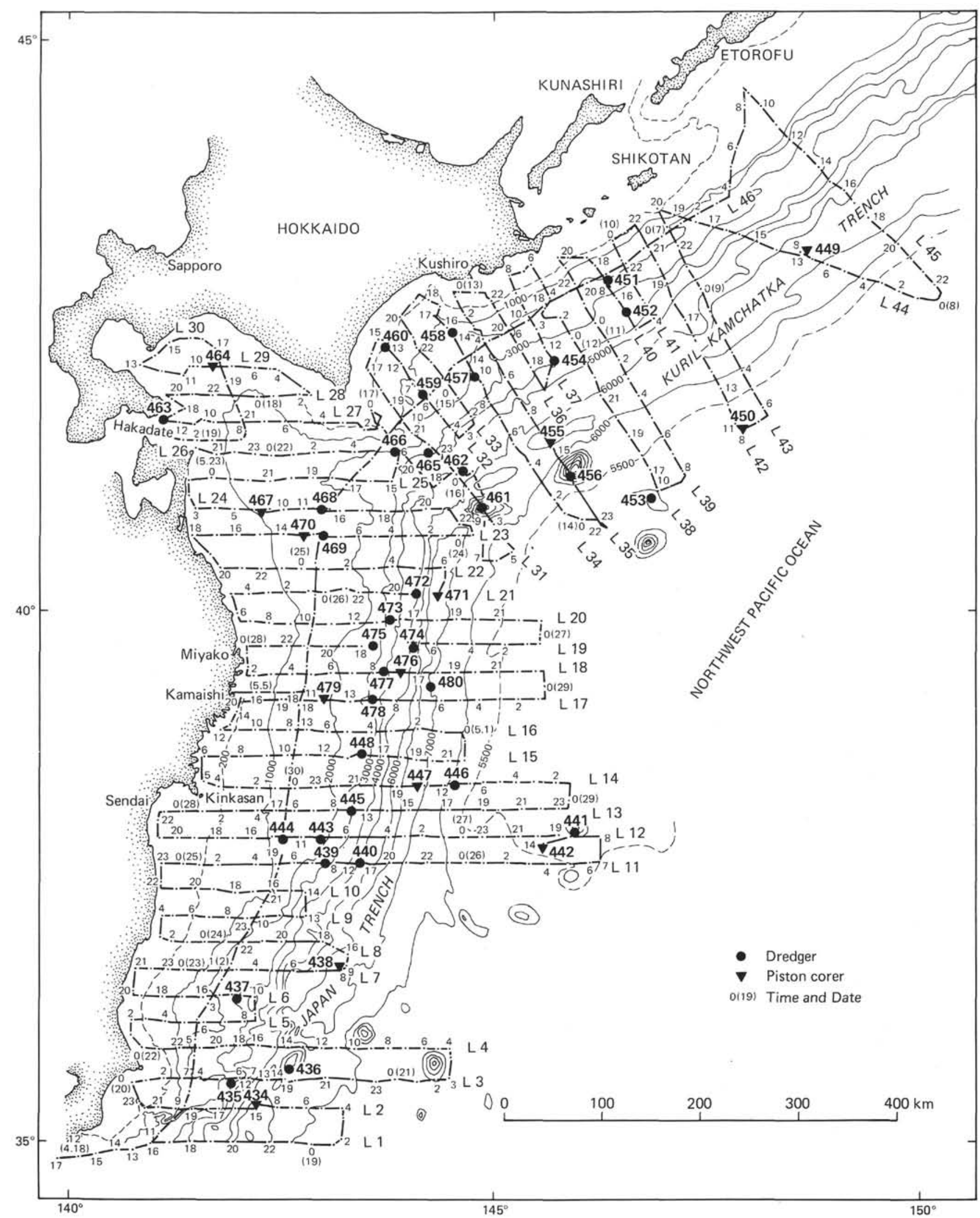

Figure 1. Sites and tracks of the geophysical survey. (Tracks in the area from $39^{\circ}-40^{\circ} \mathrm{N}, 143^{\circ}-145^{\circ} \mathrm{E}$ are shown in Figure 2.) 


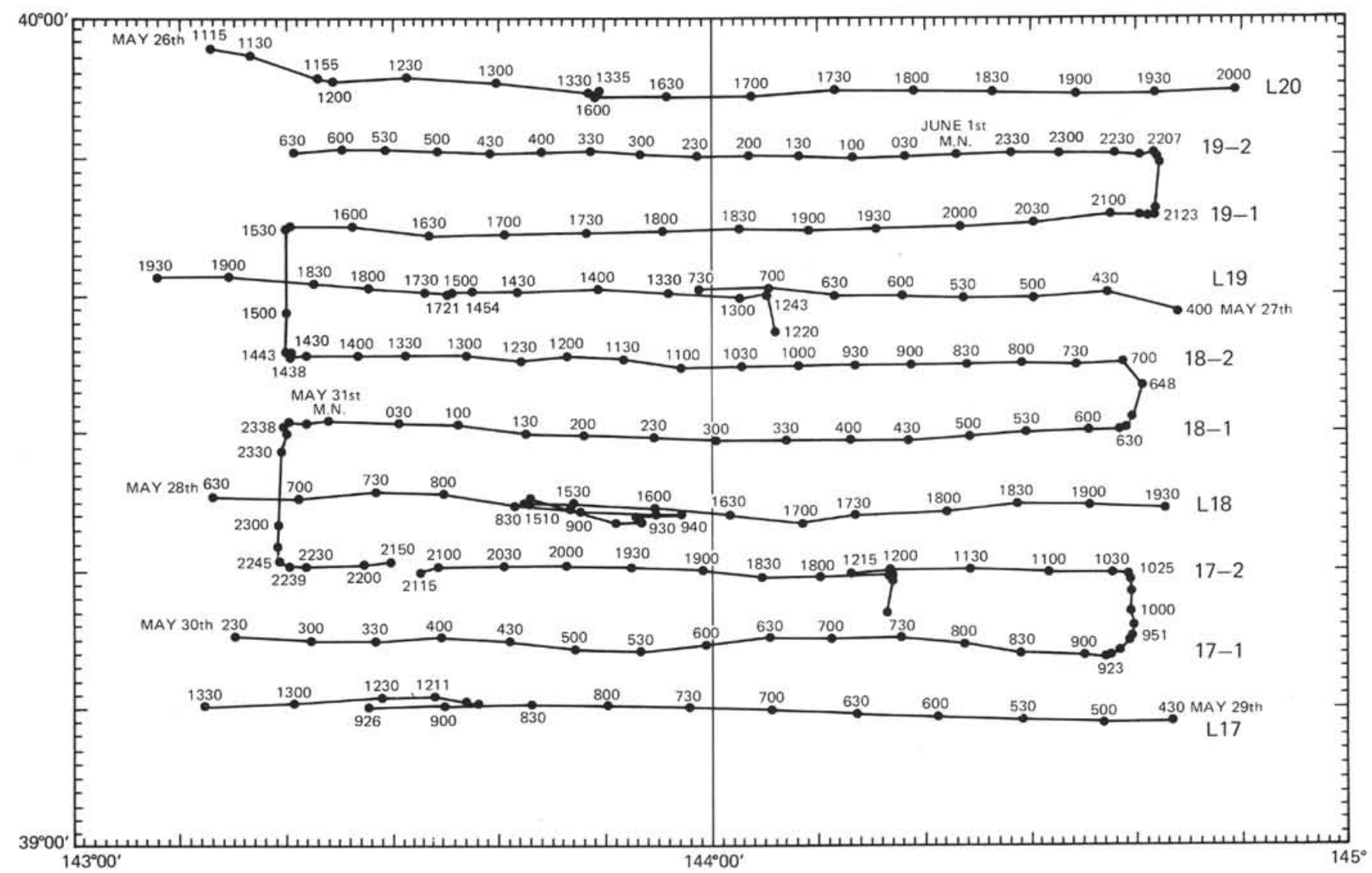

Figure 2. Tracks of the geophysical survey in a detailed survey area off Miyako, Tohoku.

part; a vaguely alternated layer below the first; and the acoustic basement, a folded, alternated pattern shown by the multichannel method (Ishiwada, 1974). The deepest layer is correlated with the Cretaceous sequence on the eastern margin of the Kitakami-Abukuma Mountains.

The structural trends of the Neogene layers are approximately parallel to the shoreline and to the trench axis, which form three distinct zones on the continental slope or deep sea terrace: (1) an uplifted zone with its axis in the nearshore land area, which can be seen as layers dipping monoclinally toward the sea on the continental shelf and on the uppermost part of the slope; (2) a subsided zone in the midslope area, which in places has flat surfaces underlain by thick Quaternary sediments; and (3) an uplifted zone at the outer margin of the slope (the trench slope break area).

There are no consolidated rocks, which are commonly observed under the continental slope and under the deep ocean floor as acoustic basement, at the inner trench slope. The sedimentary rocks are transparent beneath layered sediments near the sea floor. Overthrusts are suggested by strong diffractions dipping toward shore, which may be related to the accretionary mechanism at the inner trench slope.

Horst and graben structures at the outer trench slope are caused essentially by horizontal tensional stress created near the surface of the convex side of the bent lithosphere. However, the faults themselves are found to develop parallel to the initial spreading direction or perpendicular to the magnetic lineations rather than parallel to the trench axis (Figure 8). This fact suggests that the oceanic crust has a mechanical weakness parallel to the spreading direction and that faults are developed in the same direction as fracture zones, or transform faults, on the oceanic floor. There are no terrigenous sediments on the outer trench slope of the Japan Trench, which is in contrast to reports by Prince and Kulm (1975) which testify to their presence near the Peru-Chile Trench.

\section{DISCUSSION}

Paleogene sediments more than $2 \mathrm{~s}$ thick, which are correlated with the east coast outcrops of the Kitakami Mountains, are noted on the shelf and the nearshore slope of the northern offshore Tohoku region (Figure 9). The sedimentary basins have a northerly trend and open toward the north. The southern limit of the thick Paleogene sediments is approximately at the same latitude as Site 440. A few thinner basins are also noted in the southern area of the region.

The layers are rather conformable from Upper Cretaceous to Paleogene, with slight disconformities and a hiatus on the upper surface overlain by Neogene sequences. The hiatus beneath the Neogene sediments suggests a possible original deposition of Paleogene sediments over the whole of the slope area; however, the areas where Neogene and late Oligocene sediments unconformably overlie Upper Cretaceous strata might have 

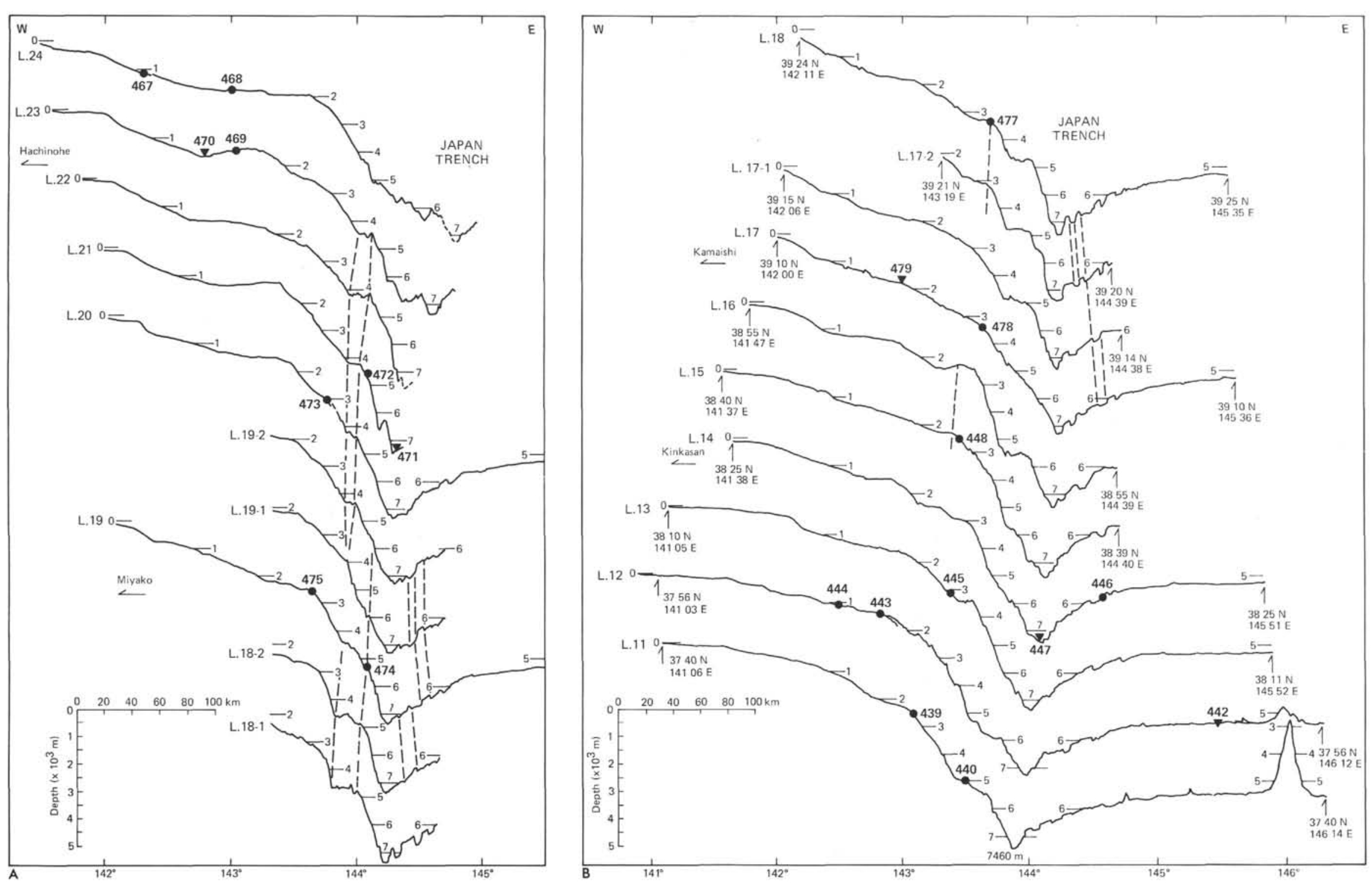

Figure 3. Topographic profiles of the northern Japan Trench. 


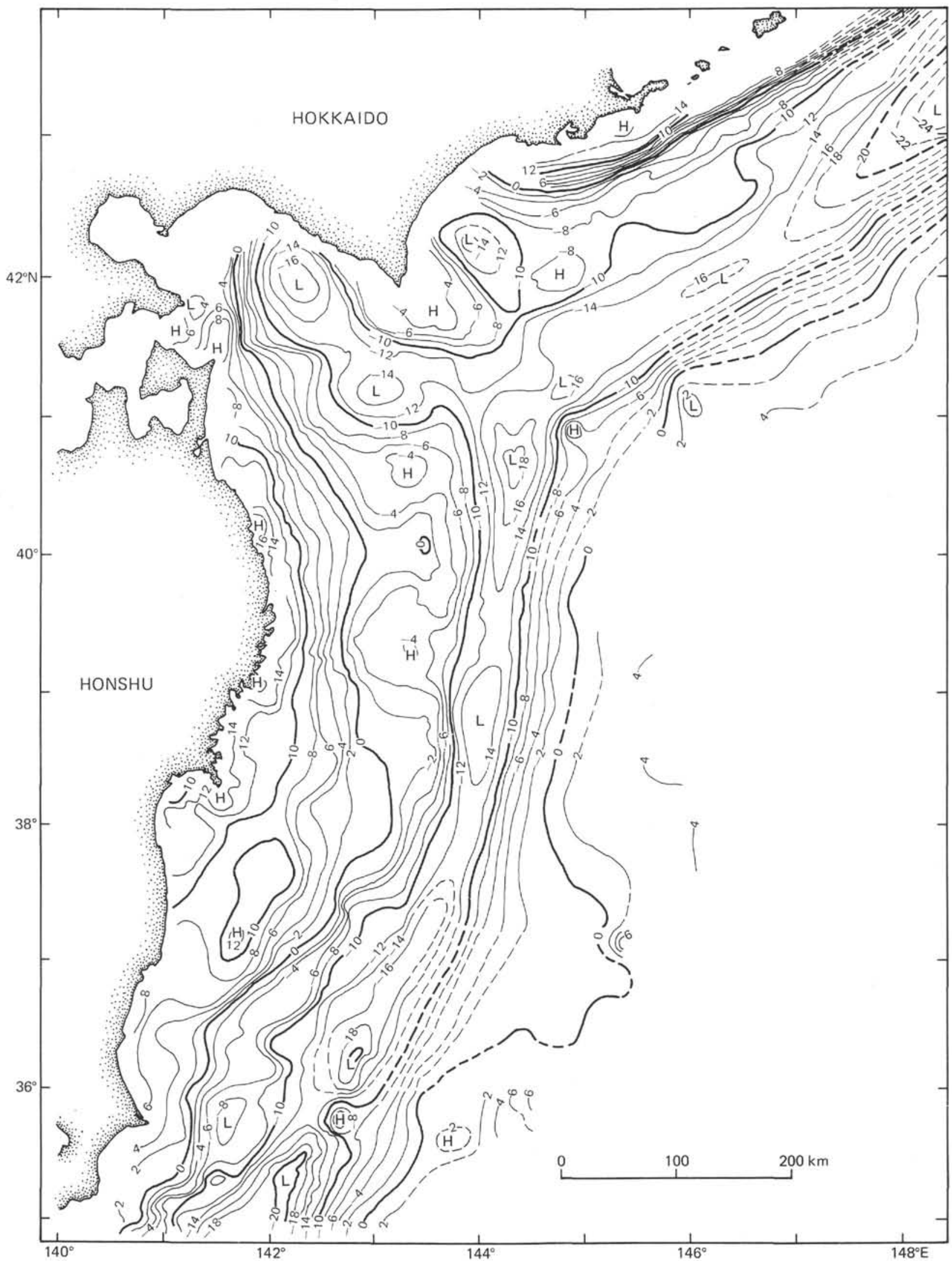

Figure 4. Contour map of free air gravity anomalies off Tohoku and Hokkaido. (Contours are in units of 10 mgal and the contour interval is 20 mgal.) 


\section{E. HONZA}

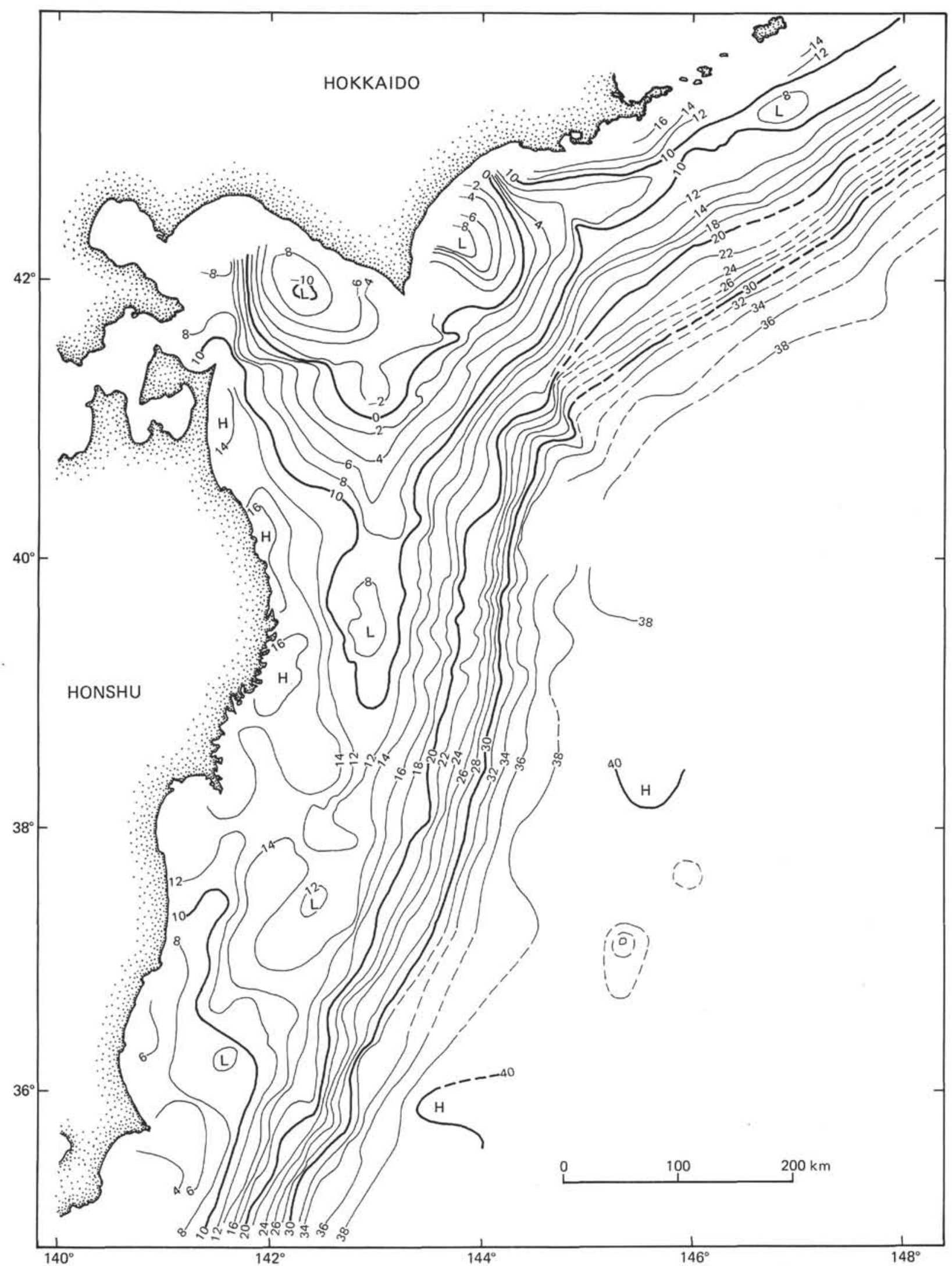

Figure 5. Contour map of Bouguer gravity anomalies off Tohoku and Hokkaido. $\left(2.67 \mathrm{~g} / \mathrm{cm}^{3}\right.$ for the subbottom density and $1.03 \mathrm{~g} / \mathrm{cm}^{3}$ for water density are used for the Bouguer correction. Contours are in units of $10 \mathrm{mgal}$ and the contour interval is $20 \mathrm{mgal}$.) 


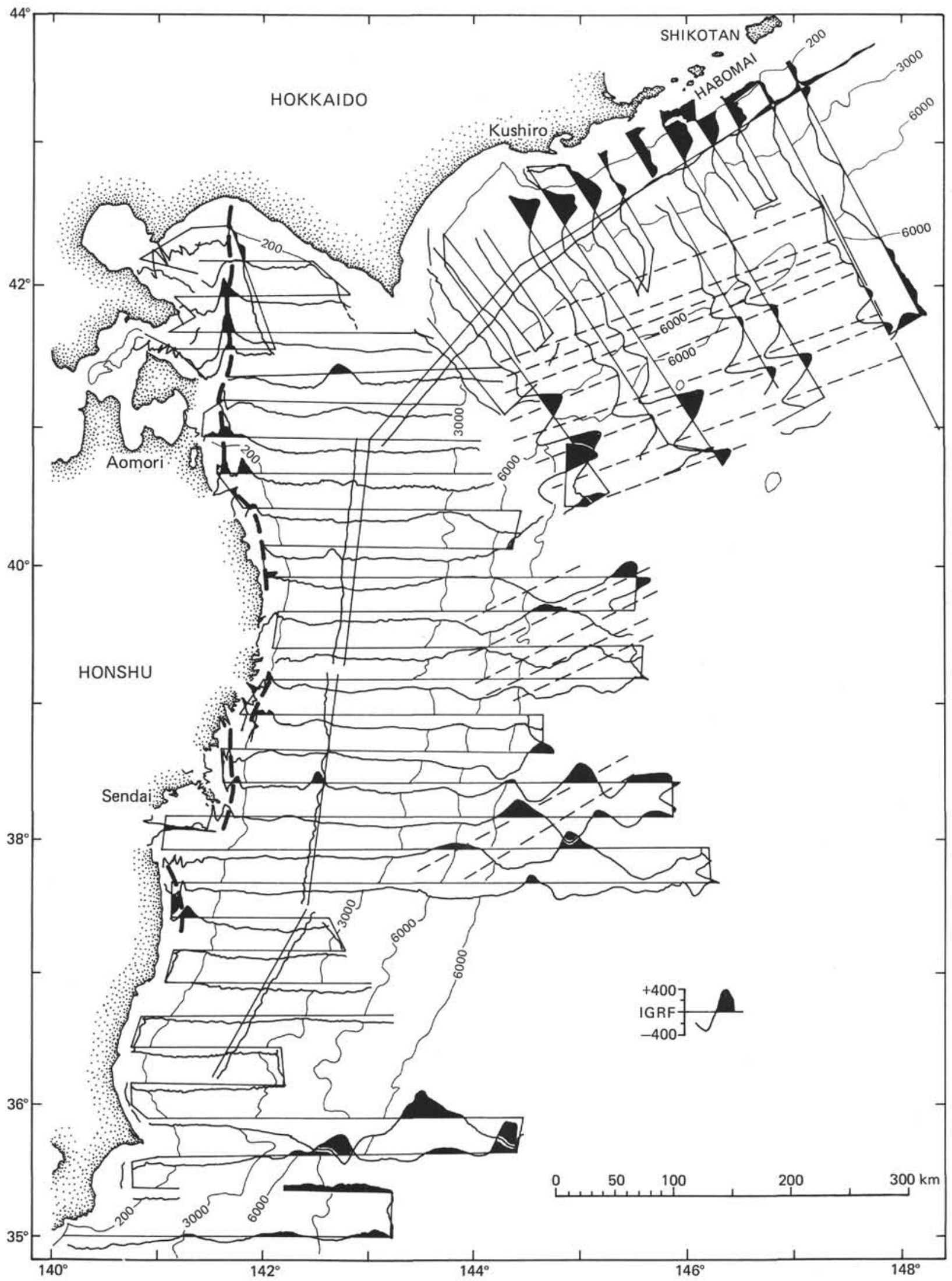

Figure 6. Magnetic anomaly profiles plotted along the tracks. (Light dashed lines are magnetic anomaly lineations in the trench area. Heavy dashed lines along the Tohoku coast are positive magnetic anomaly traces. A few magnetic high anomalies are noted on the continental slope or deep sea terrace of the Tohoku area.) 


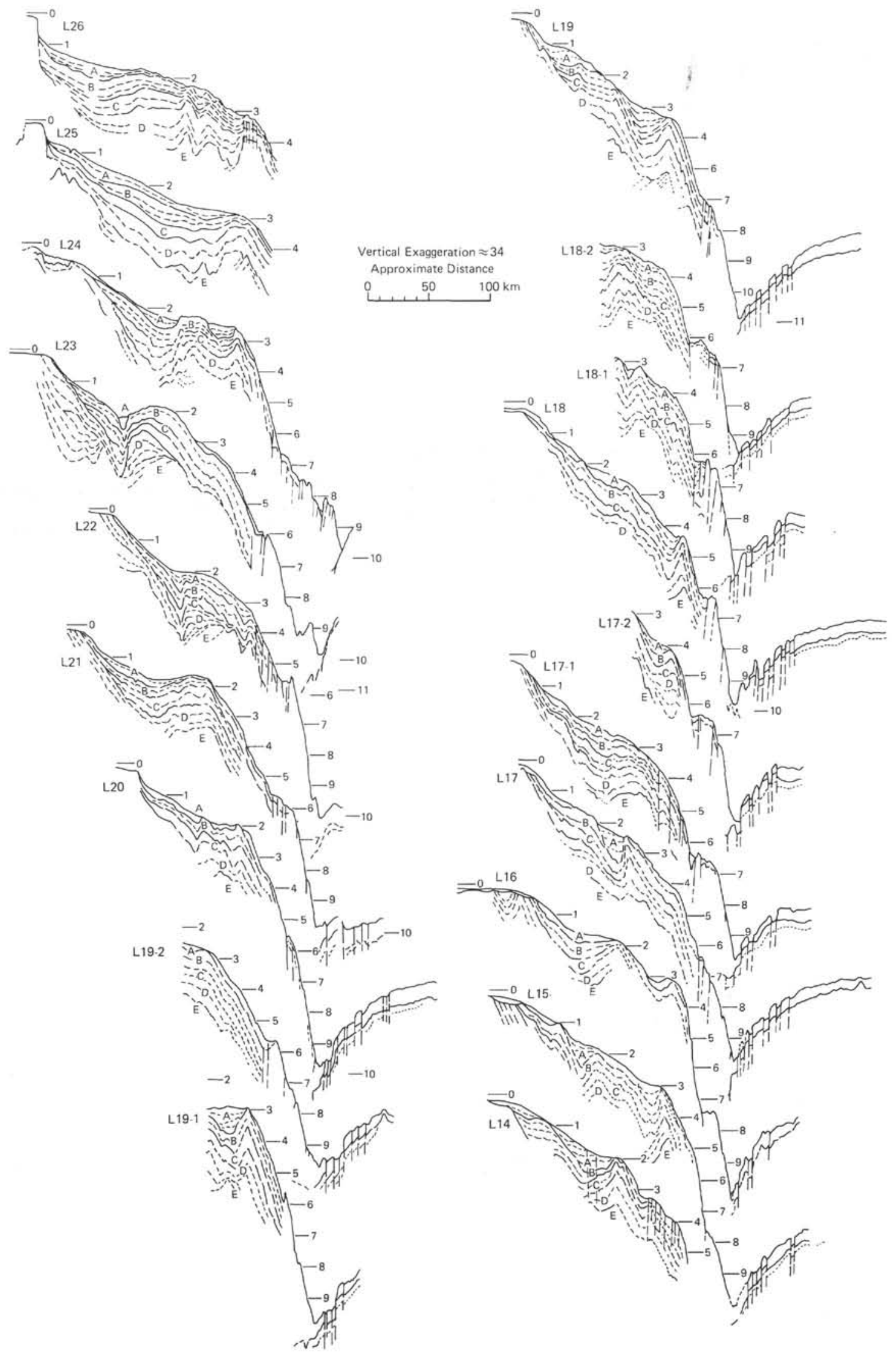

Figure 7. Continuous seismic profiling records; survey line numbers shown in Figure 1. (Vertical scale is in seconds of two-way travel time.) 


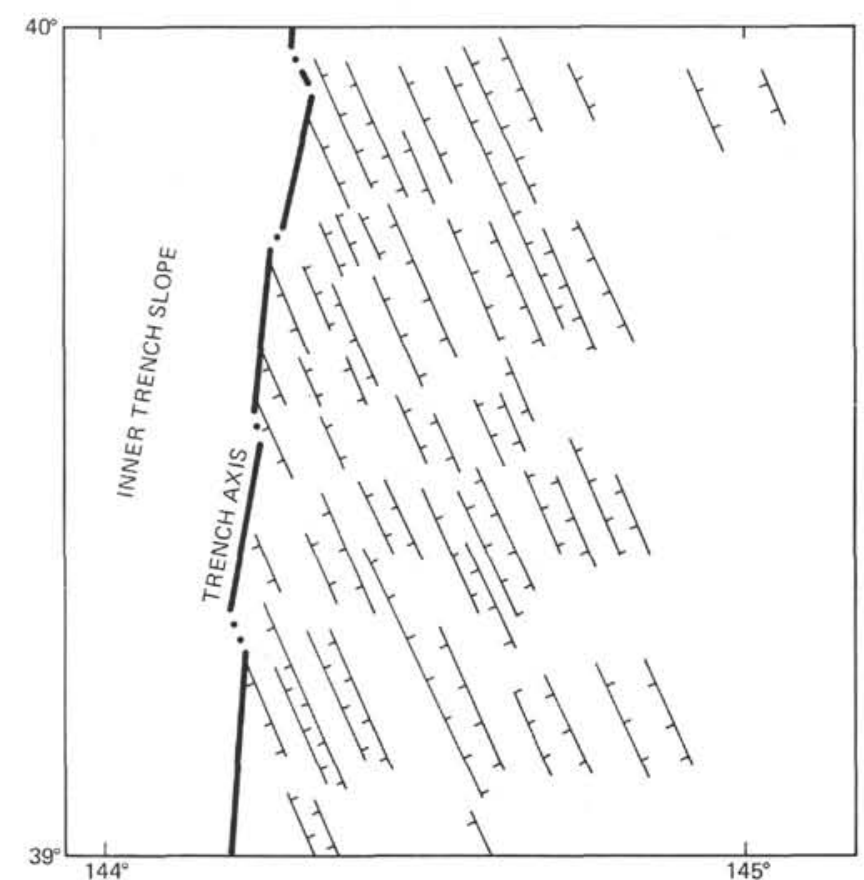

Figure 8. Horst and graben structures on the outer trench slope of the Japan Trench off Miyako. (Heavy solid lines show the trench axis.)

been highs or land areas until coarser sediments supervened during the late Oligocene to early Miocene (see lithologic descriptions in this volume). Relatively thick sediments along the coast of the Tohoku region suggest a nearby sediment supply on the outer slope from the east or southwest during the Paleogene; in other words, the dacite boulders and coarser sediment of the late Oligocene and earliest Miocene at Site 439 did not originate at the nearshore area in front of the site.

Vigorous tectonism accompanied by volcanism and regional subsidence in the inner sedimentary and volcanic belt of the Tohoku region had occurred during the late Oligocene and early Miocene in the offshore area of the Tohoku region. The Japan Trench might have been formed during this period. The tectonism is interpreted to be a beginning of the Tohoku Arc System during the Neogene and Quaternary (Honza et al., 1977).

Small folds were formed at the slope area during the late Miocene to the early Pliocene, and were accompanied by relative uplift of the coast along the Kitakami Mountain axis, subsidence in the midslope area, and uplift of the outer margin of the continental slope.

Tectonic movements modifying the outer belt of the Tohoku Arc System were accelerated during the late Pleistocene, as suggested by the faults and block structures on the shelves and slopes in front of the arc.

The accretionary prism near the Japan Trench is restricted in its development to the area beneath the lower part of the inner trench slope, as evidenced by the distribution of Cretaceous strata beneath the Neogene and Quaternary sediments on the continental slope which cannot be traced to the lower part of the inner trench slope, where diffracted and sheared patterns are dominant (see multichannel record, back pocket, this vol-

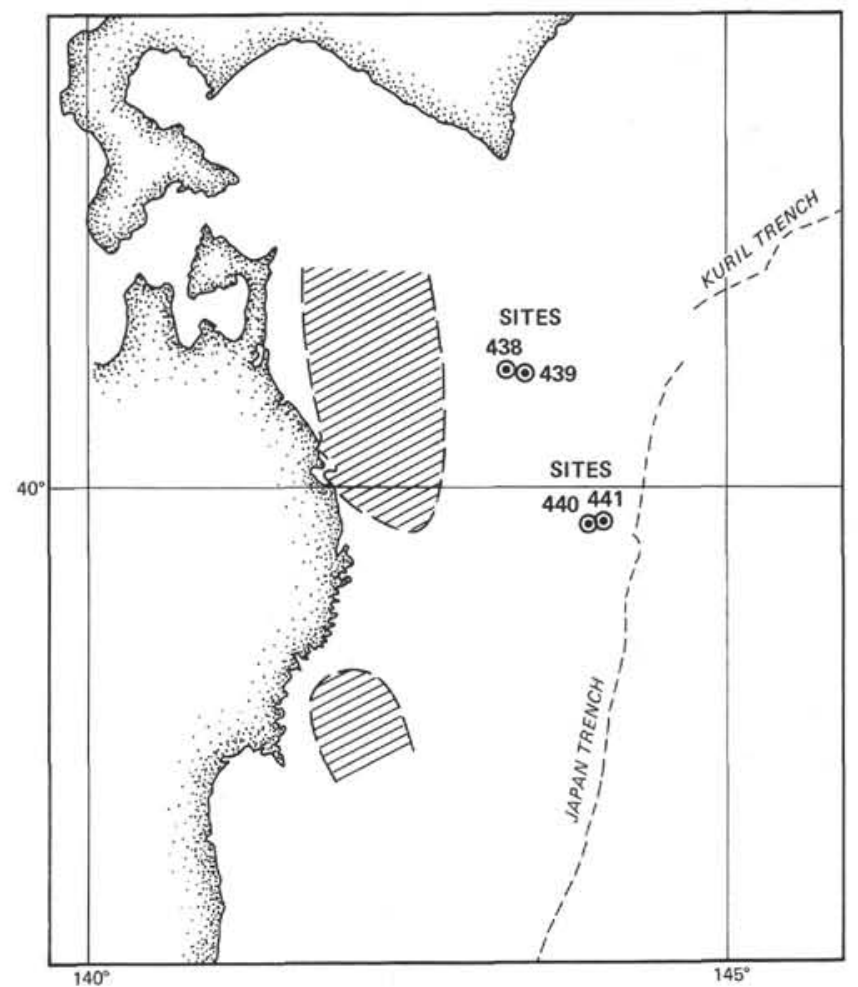

Figure 9. Inferred distribution of Paleogene sediments more than $2 s$ of two-way travel time (approximately 3 $\mathrm{km})$.

ume, Pt. 1). The boundary between the accretionary prism and continental constituents may be located at the midslope benches, where small sediment ponds in the Neogene and Quaternary are observed. Sediment-ponded benches on the inner trench slope develop discontinuously, and the length of each is restricted to that of the block structures of the continental-slope area. This fact suggests that the block structures which control the whole area of the frontal slope are related to the boundary area between the continental mass and the accretionary prism.

\section{ACKNOWLEDGMENTS}

This research was supported by the Marine Geological Research Project of the Geological Survey of Japan. The author especially wishes to acknowledge the collaboration of Kouji Onodera, Makoto Yuasa, Kensaku Tamaki, Yoshio Inouchi, Kiyokazu Nishimura, and Fumitoshi Murakami. The paper has been improved by numerous discussions and reviews with George W. Moore and Kazuaki Nakamura. The author wishes to acknowledge Manbu Tanahashi, who typed the manuscript.

\section{REFERENCES}

Hilde, T. W. C., Isezaki, N., and Wageman, J. M., 1976. Mesozoic sea-floor spreading in the North Pacific. In Sutton, G. H., Manghnani, M. H., and Moberly, R. (Eds.), The Geophysics of the Pacific Ocean Basin and Its Margin: Geophysics Monograph No. 19, pp. 205-226.

Honza, E. (Ed.), 1977. Geological Investigation of Japan and Southern Kurile Trench and Slope Areas. Geological Survey of Japan Cruise Rept. No. 7. 
Honza, E., Kagami, H., and Nasu, N., 1977. Neogene geological history of the Tohoku Island Arc System. $J$. Oceanog. Soc. Jpn., 33, 297-310.

Honza, E., Tamaki, K., and Murakami, F., 1978. Geological map of the Japan and Kuril Trenches and the adjacent areas. Geological Survey of Japan, Marine Geology Map Series, No. 11, scale 1:1,000,000.

Ishiwada, Y., 1974. Petroleum geology of the continental margin adjacent to Japanese Islands. J. Jpn. Assoc, Petrol. Tech., 39, 216-220.

Larson, R. L., and Chase, C. G., 1972. Late Mesozoic evolution of the western Pacific Ocean. Geol. Soc. Am. Bull., 83, 3627-3644.

Murakami, F., Tamaki, K., and Nishimura, K., 1977. Geomagnetic survey. In Honza, E. (Ed.), Geological Investigation of Japan and Southern Kurile Trench and Slope Areas: Geological Survey of Japan Cruise Rept. No. 7, pp. 47-49.

Nishimura, K., and Murakami, F., 1977. Gravity measurements. In Honza, E. (Ed.), Geological Investigation of Japan and Southern Kurile Trench and Slope Areas: Geological Survey of Japan Cruise Rept. No. 7, pp. 21-42.
Ogawa, K., and Suyama, J., 1976. Distribution of aeromagnetic anomalies, Hokkaido, Japan, and its geologic implication. In Aoki, H., and Iizuka, S. (Eds.), Volcanoes and the Tectonosphere: Tokyo (Tokai University Press), pp. 207-215.

Prince, R. A., and Kulm, L. D., 1975. Crustal rupture and the initiation of imbricate thrusting in the Peru-Chile Trench. Geol. Soc. Am. Bull., 86, 1639-1653.

Segawa, G., and Oshima, S., 1975. Buried Mesozoic volcanicplutonic fronts of the north-western Pacific island arcs and their tectonic implications. Nature, 256, 15-19.

Tamaki, K., Inouchi, Y., Murakami, F., and Honza, E., 1977. Continuous seismic reflection profiling survey. In Honza, E. (Ed.), Geological Investigation of Japan and Southern Kurile Trench and Slope Areas: Geological Survey of Japan Cruise Rept. No. 7, pp. 50-71.

Uyeda, S., and Vacquier, V., 1968. Geothermal and geogmagnetic data in and around the Island Arc of Japan. In Knopoff, L., Drake, C. L., and Hart, P. J. (Eds.), The Crust and Upper Mantle of the Pacific Area: Geophysics Monograph No. 12, pp. 349-366. 